\title{
Editorial: o qualis único e área mãe
}

Um leitor quis saber o motivo da revista Estação Científica (UNIFAP), ISSN 2179-1902, não possuir qualis em uma determinada área.

A revista Estação Científica (UNIFAP) não possui qualis na área que o leitor indagou pelo fato não ter tido nenhuma publicação de artigo de autor vinculado a cursos de mestrado ou de doutorado na área discutida.

A obtenção de conceito qualis acontece quando um autor vinculado a cursos de mestrado ou de doutorado, seja docente (professor que dá aula em um curso de mestrado ou de doutorado), ou discente (mestrando ou doutorando), publica um artigo em uma determinada revista e registra isto no currículo Lattes.

Assim, autores que estão vinculadas apenas a cursos de graduação ou de especialização latosensu não são englobados pela Coordenadoria de Aperfeiçoamento de Pessoal de Nível Superior (CAPES) para efeitos de concessão de qualis, pois a CAPES só trata dos cursos de mestrado e de doutorado, lembrando que é a CAPES que fornece o conceito do qualis. Quem trata de cursos de graduação é o Ministério da Educação (MEC), o qual dá o conceito do ENADE para os cursos avaliados. Em relação aos cursos de especializações lato-sensu, são as próprias instituições, em que eles funcionam, que os regem e não há emissão de classificações para as revistas, nesse caso.

Outro ponto também a ser visto é que o conceito do qualis está apenas ligado à área do curso de mestrado ou de doutorado do autor do artigo publicado. O qualis não está ligado à área da revista nem à área do artigo nem à área do vínculo profissional do autor. Por exemplo, um autor que cursa Mestrado em Geografia, o qual autor é docente em curso de graduação em Enfermagem, mas que ele escreveu um artigo sobre Antropologia e que publicou numa revista de Letras, o qualis será necessária e unicamente da área do curso do mestrado, ou seja, qualis de Geografia.

Do mesmo modo, doutores e pós-doutores que publicam artigos em revistas científicas, mas que não estejam vinculados a cursos de mestrado ou de doutorado, não possibilitam obtenção de qualis para as revistas. Nesses casos, os autores que não estão vinculados a cursos de mestrado ou de doutorado apenas complementam a quantidade de artigos que são publicados em cada edição de uma revista. Por isso que algumas revistas objetivam apenas divulgar a produção científica, e aceitam artigos de autores que estão ou não vinculados a cursos de mestrado ou de doutorado. Há algumas revistas que só almejam conceitos de qualis, e que só aceitam artigos de autores que estão vinculados a cursos de pós-graduação stricto-sensu.

Atualmente, está em discussão na CAPES a concessão do qualis-único para as revistas, que seria mais ou menos um único conceito de qualis de uma única área preponderante na revista. Assim, no formato atual, uma revista pode ter vários qualis de várias áreas. Porém, no novo formato que deverá ser implantado em 2021, com a divulgação do resultado do quadriênio 2017-2020, da CAPES, as revistas terão perda de conceitos qualis de diversas áreas e passarão a ter o conceito de qualis de uma só área, justamente da área em que ela teve a maior quantidade de autores vinculados.

Por exemplo, uma revista que hoje possui conceito de qualis em Economia, Educação Física e História, e no final do quadriênio de 2017-2020, em que teve maior quantidade de autores da 
área de História, passará a ter o qualis-único apenas da área de História e nenhum outro mais. Se por um acaso, a revista quiser estabelecer a própria área de qualis, ela deverá, então, passar a selecionar o perfil de vínculo dos autores e privilegiar o processo editorial com maior incidência dos autores da área que ela deseja ter o qualis-único preponderante. Este procedimento, a longo prazo, possibilitará às revistas focarem-se nos artigos dos autores de suas áreas-mãe, ou seja, a área que a revista escolheu publicar pelo seu perfil de afinidade teórica e editorial. Assim, a longo prazo, as revistas ganharão mais qualidade, foco temático e condensamento teórico das edições, e serão melhores referenciais e bases de pesquisa da área.

Boa leitura a todos/as.

Atenciosamente,

Fernando Castro Amoras

Editor-chefe da revista Estação Científica (UNIFAP) 